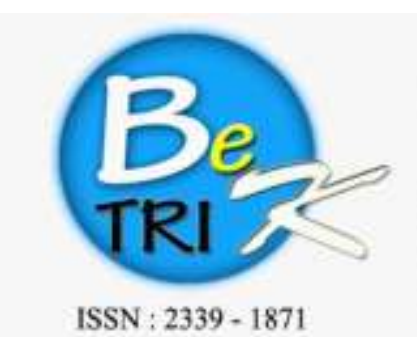

\section{JURNAL ILMIAHBETRIK Besemah Teknologi Informasi dan Komputer}

Editor Office : LPPM Sekolah Tinggi Teknologi Pagar Alam, Jn. Masik Siagim No. 75 Simpang Mbacang, Pagar Alam, SUM-SEL, Indonesia Phone: $+62852-7901-1390$.

Email : betrik@lppmsttpagaralam.ac.id | admin.jumal@lppmsttpagaralam.ac.id Website : hups://ejournal.lppmstipagaralam.ac.id/index.php/betrik/index

\title{
PENDUGAAN TINGGI PASANG SURUT LAUT HARIAN MENGGUNAKAN JARINGAN SYARAF TIRUAN METODE BACKPROPAGATION
}

\author{
Eko Suryana \\ Dosen Teknik Informatika, Universitas Dehasen Bengkulu \\ Jl. Meranti Raya No.32, Sawah Lebar, Ratu Agung, Bengkulu, 38222 \\ Sur-el : ekosuryana@unived.ac.id
}

\begin{abstract}
Artificial Neural Network Model with methods Backrpopagation authors try to be implemented in the estimation or prediction of high tidal waters in Bengkulu. Neural Network architecture that is built consisting of three layers namely input layer, hidden layer and output layer. Estimation tidal itself always relies on historical data of the place concerned. A person can not make a prediction of ocean tides in a particular region in the absence of historical data in the region in a time sequence. Time series data is used as a basis of the estimation of data so as to recognize the tidal patterns that occur which in turn can be used as a reference to estimate the number of ups and downs that will occur. In this study, preprocessing or initial process carried out by the method of Backpropagation, where there are several steps that lead levels that this initial process can be carried out with the best. Changing the data type in the desired interval by Artificial Neural Networks will determine the next processing step. The sequence of steps taken in this prepocessing is selecting the data, data cleaning, transformation of data
\end{abstract}

Keywords: Tidal, Neural Network, Backpropagation,

\begin{abstract}
Abstrak :Model Jaringan Syaraf Tiruan dengan metode Backrpopagation penulis coba diimplementasikan dalam perkiraan atau prediksi pasang surut air laut di Bengkulu. Arsitektur Jaringan Syaraf Tiruan yang dibangun terdiri dari tiga lapisan yaitu lapisan input, layer tersembunyi dan lapisan output. Estimasi pasang surut sendiri selalu mengandalkan data historis tempat yang bersangkutan. Seseorang tidak dapat membuat prediksi pasang surut air laut di wilayah tertentu karena tidak adanya data historis di wilayah tersebut dalam urutan waktu. Data deret waktu digunakan sebagai dasar estimasi data sehingga mengenali pola pasang surut yang terjadi yang pada gilirannya dapat dijadikan acuan untuk memperkirakan jumlah pasang surut yang akan terjadi. Dalam penelitian ini, proses preprocessing atau initial dilakukan dengan metode Backpropagation, dimana ada beberapa langkah yang memimpin level dimana proses awal ini dapat dilakukan dengan sebaik-baiknya. Mengubah tipe data dalam interval yang diinginkan oleh Jaringan Syaraf Tiruan akan menentukan langkah pemrosesan
\end{abstract}


selanjutnya. Urutan langkah yang ditempuh dalam prepocessing ini adalah pemilihan data, pembersihan data, transformasi data

Kata kunci: Tidal, NeuralNetwork, Backpropagation,

\section{PENDAHULUAN}

Wilayah Provinsi Bengkulu yang berbatasan langsung dengan Samudera Indonesia pada garis pantai sepanjang 525 kilometer, terletak pada bagian Barat dan merupakan dataran rendah yang relatif sempit, memanjang dari Utara ke Selatan serta diselang-selingi daerah yang bergelombang, sedangkan pada bagian Timur berbukit-bukit dengan dataran tinggi yang subur. Perairan Bengkulu, sangat rawan akan terjadi gelombang tinggi dadakan karena berhadapan langsung dengan Samudra Hindia termasuk perairan Lampung dan Banten.

Oleh karenanya, dianggap penting menghitung dan memperkirakan tinggi pasang surut laut yang dihitung secara periode harian agar segala aktivitas atau kegiatan yang dilakukan dilaut Bengkulu dapat dipersiapkan sebelumnya.

Pasang surut adalah fluktuasi muka air laut sebagai fungsi waktu karena adanya gaya tarik benda-benda di langit, terutama matahari dan bulan terhadap massa air laut dibumi. Meskipun massa di bulan jauh lebih dekat, maka pengaruh gaya tarik bulan terhadap bumi lebih besar dari pada pengaruh gaya tarik matahari.

Banyak metode pendugaan dan prediksi yang digunakan untuk memperkirakan pasang surutnyagelombang laut. Hal ini sangat penting untuk dilakukan karenadapat mempengaruhi kehidupan manusia. Karenanya, mengetahui perkiraannya akan sangat membantu dalam proses perencanaan pada berbagai bidang kehidupan, terlebih lagi dalam fungsinya sebagai pencegah dalam managemen bencana, sehingga bahaya yang lebih besar dapat dihindarkan. Semakin baik teknik prediksi yang digunakan tentu semakin menjamin keberlangsungan kehidupan, oleh karenanya segala cara dicoba dan dibandingkan guna mencari teknik terbaik. Salah satu dari sekian cara itu adalah bidang ilmu komputer. Bidang ilmu pengetahun komputer science memberikan harapan baru dengan teknik Artificial Intelligence.

Teknik Artificial Intelligent telah banyak digunakan untuk melakukan berbagai prediksi. Salah satu teknik Artificial Intelligent yang banyak digunakan untuk keperluan ini adalah metode Jaringan Syaraf Tiruan (JST) dengan algoritma back-propagation. JST dengan back-propagation network (BPN) banyak digunakan untuk membuat berbagai prediksi, termasuk prediksi tentang kecepatan angin atau bahkan untuk memprediksi cuaca (Paras, et al). Selain digunakan untuk keperluan di atas, Artificial Intelligent khususnya teknik Jaringan Syaraf Tiruan khususnya algoritma backpropagation banyak digunakan untuk pendugaan lain yang sifatnya lebih luas. 


\section{METODOLOGI PENELITIAN}

\section{a. Artificial \\ Intelligence (Kecerdasan}

Buatan)

MenurutRusell dan Norvig, Artificial Intelligence (AI) merupakan bagian ilmu pengetahuan yang digunakan untuk menyelesaikan masalah manusia dengan cara memahami, memprediksi dan memanipulasi (Marleni Anike et al.,2012).

Sedangkan menurut Coppin, kecerdasan yang dibuat untuk sistem menggunakan algoritma tertentu sehingga sistem seolah-olah dapat berpikir seperti manusia (Marleni Anike et al.,2012).

Untuk menerapkan aplikasi kecerdasan buatan ada dua bagian utama yang dibutuhkan, yaitu :

\section{Basis Pengetahuan (Knowledge}

Base),berisi pengetahuan-pengetahuan, teori-teori, pemikiran dan hubungan antara satu dengan yang lain.

2. Motor Inferensi (Inference Engine), yaitu kemampuan menarik kesimpulan berdasarkan pengalaman.

\section{b. Jaringan Syaraf Tiruan}

Dengan memanfaatkan kemajuan di bidang teknologi dan informasi yang semakin pesat saat ini, dapat dirancang sebuah sistem Jaringan Syaraf Tiruan (Artificial Neural Network) dalam memprediksi tinggi pasang surut laut. Menurut Kiki dan Kusumadesi Jaringan Syaraf Tiruan (JST) merupakan salah satu cabang dari AI (Artificial Intelligence) atau kecerdasan buatan. Jaringan Syaraf Tiruan merupakan salah satu sistem pemrosesan informasi yang didesain dengan menirukan cara kerja otak manusia dalam menyelesaikan suatu masalah dengan melakukan proses belajar melalui perubahan bobot yang diterimanya. JST mampu melakukan pengenalan kegiatan berbasis data masa lalu atau belajar dari pengalaman. Data masa lalu akan dipelajari oleh Jaringan Syaraf Tiruan sehingga mempunyai kemampuan untuk memberikan keputusan terhadap data yang belum pernah dipelajari (Badrul Anwar, 2012). Jaringan perambatan galat mundur (backpropagation) merupakan salah satualgoritma Jaringan Syaraf Tiruan yang sering digunakan dalam menyelesaikan masalah-masalah yang rumit berkaitan dengan identifikasi, prediksi pengenalan pola dan sebagainya. Hal ini dimungkinkan karena jaringan dengan algoritma ini dilatih dengan menggunakan metode belajar terbimbing.

Menurut Hermawan pelatihan dilakukan berulang-ulang sehingga dihasilkan jaringan yang memberikan tanggapan yang benar terhadap semua masukannya. Hal ini merupakan kelebihan dari Jaringan Syaraf Tiruan backpropagation sehingga dapat mewujudkan sistem yang tahan akan kerusakan dan konsisten bekerja dengan baik (Badrul Anwar, 2012).

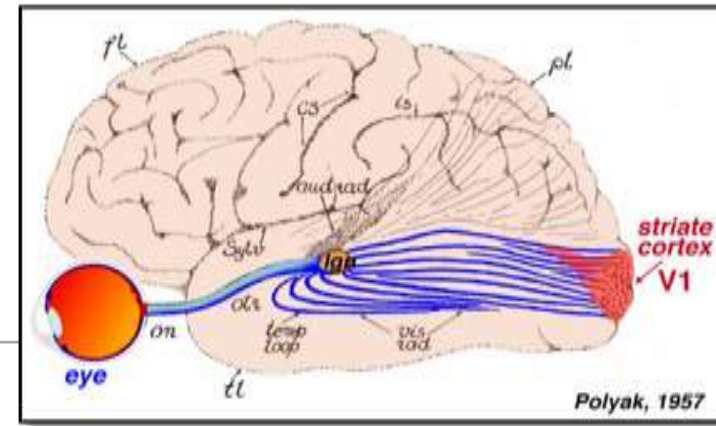


Gambar 1. Jaringan Syaraf Otak Manusia

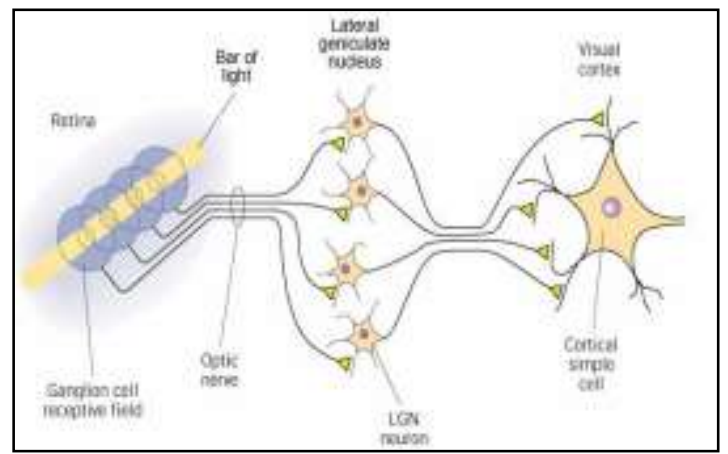

Gambar 2. Jaringan Syaraf Otak Manusia

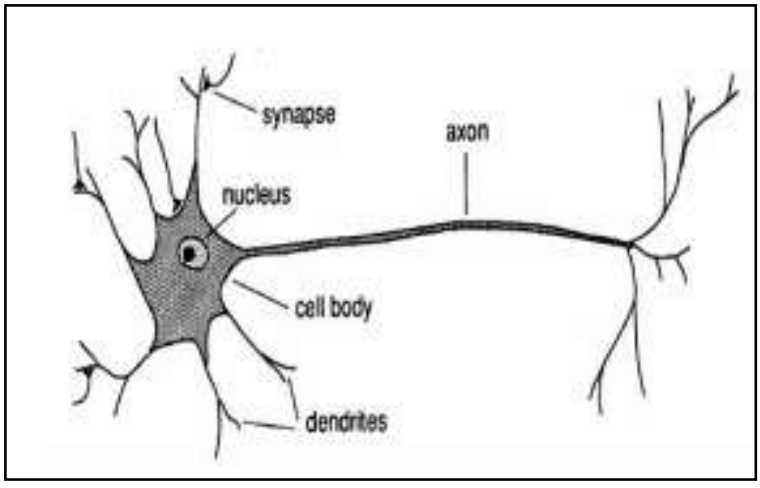

Gambar 3. Komponen Neuron

Dari gambar 3. terlihat bahwa dari tubuh neuron keluar dendrite ke neuron yang lain. Neuron - neuron tersebut menerima sinyal pada sebuah ujung sambungan yang disebut sinapsis. Jaringan Syaraf Tiruan adalah sistem komputasi di mana arsitektur dan operasi diilhami dari pengetahuan tentang sel syaraf biologi di dalam otak. Jaringan Syaraf Tiruan dibentuk sebagai generalisasi model matematika dari jaringan syaraf biologi, dengan asumsi bahwa:

a. Pemprosesan informasi terjadi pada banyak elemen sederhana (neuron). b. Sinyal dikirim diantara neuron-neuron melalui penghubung-penghubung.

c. Penghubung antar neuron memiliki bobot yang akan memperkuat ataau

d. memperlemah sinyal.

e. Untuk menentukan output, setiap neuron menggunakan fungsi aktivasi (biasanya bukan fungsi linier) yang dikenakan pada jumlah input yang diterima. Besarnya output ini selanjutnya dibandingkan dengan batas ambang.

Jaringan Syaraf Tiruan ditentukan oleh tiga hal yaitu:

1) Pola hubung antar neuron (disebut arsitektur jaringan)

2) Metode untuk menentukan bobot penghubung (disebut metode training/learning/algoritma).

3) Fungsi aktivasi.

4) Jika suatu masukan/input melewati suatu ambang tertentu, maka neuron tersebut akan diaktifkan, tetapi kalau tidak, maka neuron tersebut tidak akan diaktifkan.

\section{c. Backpropagation}

Jaringan Syaraf Tiruan propagasi balik adalah Jaringan Syaraf Tiruan dengan topologi multi-lapis (multilayer) dengan satu lapis masukan (lapis $X$ ), satu atau lebih lapis hidden atau tersembunyi (lapis $Z$ ) dan satu lapis keluaran (lapis Y). Setiap lapis memiliki neuron-neuron (unit-unit) yang dimodelkan dengan lingkaran Di antara neuron pada satu lapis dengan neuron pada lapis berikutnya dihubungkan dengan model koneksi yang memiliki bobot-bobot (weights), w dan $\mathbf{v}$. Lapis tersembunyi dapat memiliki bias, yang memiliki bobot sama dengan satu. 


\section{Arsitektur Backpropagation}

Backpropagation memiliki beberapa unit yang ada dalam satu atau lebih layer tersembunyi. Gambar 2 adalah arsitektur backpropagation dengan $n$ buah masukan (ditambah sebuah bias), sebuah layer tersembunyi yang terdiri dari $p$ unit (ditambah sebuah bias), serta m buah unit keluaran.

Dapat dijelaskan bahwa $v_{j i}$ merupakan bobot garis dari unit masukan $x_{i}$ ke unit layer tersembunyi $z_{j}\left(v_{j 0}\right.$ merupakan bobot garis yang menghubungkan bias di unit masukan ke unit layer tersembunyi $z_{j}$ ). $w_{k j}$ merupakan bobot dari unit layer tersembunyi $z_{j}$ ke unit keluaran $y_{k}$ ( $w_{k}$ merupakan bobot dari bias di layer tersembunyi ke unit keluaran $z_{k}$ ).

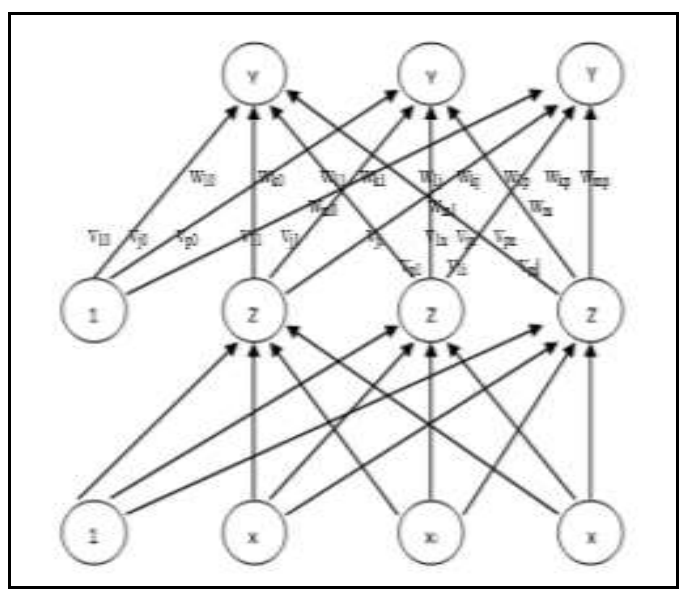

Gambar 4. Arsitektur Jaringan Backpropagation

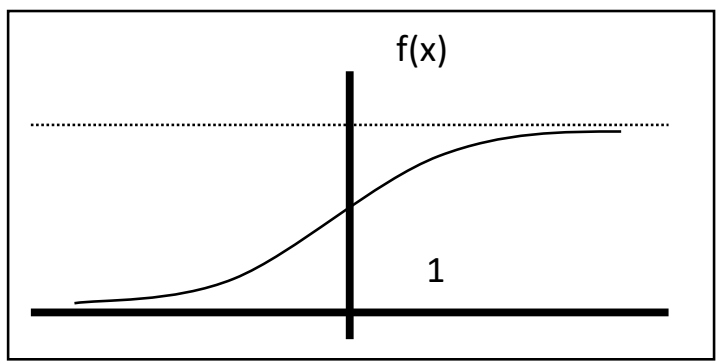

Gambar 5. Fungsi Sigmoid Biner Dengan Range (0,1)

Fungsi lain yang sering dipakai adalah fungsi sigmoid bipolar yang bentuk fungsinya mirip dengan fungsi sigmoidbiner, tetapi dengan range $(-1,1)$

$f(x)=\frac{2}{1+e^{-x}}-1 \quad$ dengan turunan $\quad f^{\prime}(x)$

$=\frac{(1+f(x))(1-f(x))}{2}$

Fungsi sigmoid memiliki nilai maksimum $=1$ untuk pola yang targetnya $>1$, pola masukan dan keluaran harus terlebih dahulu di transformasi sehingga semua pola mempunyai range yang sama seperti rang yang dipakai. Jalan lain yaitu menggunakan fungsi aktivasi sigmoid hanya pada layer yang bukan layer keluaran. Layer keluaran untuk fungsi aktivasi yang dipakai menggunakan fungsi identitas : $f(x)=x$

\section{d. Pengertian Pendugaan Atau Peramalan}

Menurut Nasution Pendugaan atau Peramalan adalah proses untuk memperkirakan berapa kebutuhan dimasa yang akan datang yang meliputi kebutuhan dalam ukuran kuantitas, kualitas, waktu dan lokasi yang dibutuhkan dalam rangka memenuhi permintaan barang ataupun jasa (Fachrudin, et. al., 2012).

Menurut Makridaksi pada dasarnya pendekatan peramalan dapat diklasifikasikan menjadi dua pendekatan, yaitu (Fachrudin, et. al., 2012) :

1. Pendekatan kualitatif

2. Pendekatan kuantitatif

Menurut Makridaksi Pola Data Peramalan Time Series ada 4 jenis pola data dalam pendugaan atau peramalan (Fachrudin, et. al., 2012) yaitu : 
1. Trend : Pola data tren menunjukkan pergerakan data cenderung meningkat atau menurun dalam waktu yang lama.

2. Seasonality (musiman) : Pola data musiman terbentuk karena faktor musiman, seperti cuaca dan liburan.

3. Cycles (Siklus) : Pola data siklus terjadi jika variasi data bergelombang pada

durasi lebih dari satu tahun dipengaruhi oleh faktor politik, perubahan ekonomi

(ekspansi atau kontraksi) yang dikenal dengan siklus usaha.

\section{e. Pengertian Pasang Surut}

Menurut Nontji Pasang surut adalah gerakan naik turunnya muka laut secara berirama yang disebabkan oleh gaya tarik bulan dan matahari. Akan tetapi bulan mempunyai peranan yang lebih besar daripada matahari dalam menentukan pasang surut karena jarak lebih menguntungkan daripada massa (Alfi Faridatus, et al., 2014).

Menurut Suyasa, dkk ada dua macam pasang-surut, yaitu pasang surut purnama (spring tide) dan pasang surut perbani (neap tides). Pasang surut purnama (spring tide) yaitu pasang surut dengan amplitudo besar yang disebabkan karena medan gravitasi bulan dan matahari menarik air laut pada arah yang sama, dan keadaan ini terjadi ketika bulan baru atau bulan penuh. Sedangkan pasang surut perbani (neap tides) adalah pasang surut dengan amplitudo kecil yang terjadi karena gaya gravitasi matahari posisinya berada tegak lurus terhadap gaya gravitasi bulan, sehingga kedua gaya gravitasi tersebut memberikan efek yang kecil, dan terjadi ketika perempat bulan pertama dan perempat bulan terakhir. Kedua pasang surut tersebut terjadi dua kali dalam satu siklus bulan yang lamanya 28 hari ((Alfi Faridatus, et al., 2014).

Bentuk pasang surut di berbagai daerah tidak sama. Di suatu daerah dalam satu hari dapat terjadi satu kali pasang surut. Secara umum pasang surut di berbagai daerah dapat dibedakan empat tipe, yaitu pasang surut harian tunggal (diurnal tide), harian ganda (semidiurnal tide) dan dua jenis campuran.

1. Pasang Surut Harian Ganda (Semi Diurnal Tide)

Dalam satu hari terjadi dua kali air pasang dan dua kali air surut dengan tinggi yang hampir sama dan pasang surut terjadi secara berurutan secara teratur. Tipe pasang surut rata-rata adalah 12 jam 24 menit. Pasang surut jenis ini terdapat di selat Malaka sampai laut Andaman.

2. Pasang Surut Harian Tunggal (Diurnal Tide) Dalam satu hari terjadi satu kali air pasang dan satu kali air surut dengan periode pasang surut adalah 24 jam 50 menit. Pasang surut tipe ini terjadi di perairan selat Karimata.

3. Pasang Surut Campuran Condong Ke Harian Ganda(Mixed Tide Prevelailing Semidiurnal Tide)

Dalam satu hari terjadi dua kali air pasang dan dua kali air surut, tetapi tinggi dan dan periodenya berbeda. Pasang surut jenis ini banyak terdapat di perairan Indonesia Timur.Pasang Surut Campuran Condong Ke Harian Tunggal (Mixed Tide Prevelailing Diurnal Tide)Pada tipe ini, dalam satu hari terjadi satu kali air pasang dan satu kali air surut, tetapi kadang-kadang 
untuk sementara waktu terjadi dua kali pasang dan dua kali surut dengan tinggi dan periode yang sangat berbeda. Pasang surut jenis ini terdapat selat Kalimantan dan pantai utara Jawa Barat.

\section{HASIL DAN PEMBAHASAN}

\subsection{Pengolahan Jaringan SyarafTiruan} Dengan Menggunakan Matlab 2013a

Matlab singkatan dari Matrix Laboratory. Matlab merupakan bahasa pemrogaman yang dikembangkan oleh The Mathwork. Inc. Pada awalnya, program ini merupakan interface untuk koleksi rutin-rutin numerik dari proyek LINPACK dan EISPACK, namun sekarang merupakan produk komersial dari perusahaan Mathworks, Inc. MATLAB telah berkembang menjadi sebuah environment pemrograman yang canggih yang berisi fungsi-fungsi built-in untuk melakukan tugas pengolahan sinyal, aljabar linier, dan kalkulasi matematis lainnya. $M A T L A B$ juga berisi toolbox yang berisi fungsi-fungsi tambahan untuk aplikasi khusus.

Pengolahan dan inisialisasi Jaringan Syaraf Tiruan dilakukan dengan bantuan software $\quad$ MATLAB ${ }^{\circledR} \quad$ (MATRIX LABORATORY) versi 2013a, MATLAB adalah sebuah software yang sangat berguna dalam analisis numerik. Matlab menyediakan lingkungan kerja yang lengkap baik untuk komputasi maupun visualisasi. Berikut ini gambar tampilan wellcome screen dari Matlab 2013a.

Tampilan awal dari MATLAB 2013a seperti terlihat pada gambar 6 di bawah ini :

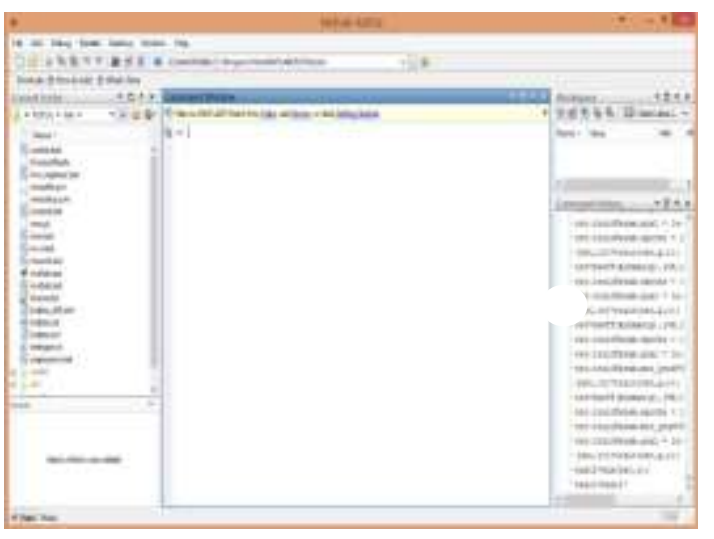

Gambar 6. Tampilan awal MATLAB 2013.a

\subsection{Pelatihan Jaringan}

Supaya dapat mengenali pola data masukan, maka Jaringan Syaraf Tiruan yang dibangun harus dilatih terlebih dahulu. Pelatihan menggunakan berbagai arsitektur Jaringan Syaraf Tiruan yang telah ditentukan pada bab IV. Adapun parameter-parameter pelatihan yang ditentukan untuk semua kombinasi arsitektur pelatihan adalah :

1. Semua nilai pemberat dan nilai bias di inisialisasi oleh sistem.

2. Banyaknya epoch maksimal ditentukan 20000 epoch

3. Toleransi atau nilai MSE yang ingin dicapai adalah 10 e-004 (goal)

4. Sedangkan parameter yang lain ditetapkan seseuai dengan nilai default dari matlab

Perintah yang digunakan untuk membentuk Jaringan Syaraf Tiruan pada matlab adalah:

$$
\begin{aligned}
& n e t=n e w f f\left(P R,\left[\begin{array}{llll}
S 1 & S 2 & \ldots S N
\end{array}\right],\left\{\begin{array}{llll}
T F 1 & T F 2 & \ldots
\end{array}\right.\right. \\
& T F N\}, B T F, B L F, P F)
\end{aligned}
$$

dimana:

Net $=$ Jaringan Backpropagation yang terdiri dari $n$ layar

$P R=$ Matriks ordo $\mathrm{Rx} 2$ yang berisi nilai minimum dan maksimum $R$ 
buah elemen masukannya

$S i=$ Jumlah unit pada layar ke $i$ (i $=$ $1,2, \ldots, \mathrm{n})$

$T F i=$ Fungsi aktivasi yang dipakai pada layar ke $i(\mathrm{i}=1,2, \ldots, \mathrm{n})$.

Defaultnya $=$ tansig (sigmoid bipolar)

$\mathrm{BTF}=$ Fungsi pelatihan jaringan. Defaultnya $=$ traingdx

$\mathrm{BLF}=$ Fungsi perubahan bobot $/$ bias. Defaultnya $=$ learngdm

$\mathrm{PF}=$ Fungsi perhitungan error. Default $=$ mse.

Perintah diatas secara otomatis akan menentukan bobot dan bias bagi jaringan yang anda bentuk dengan bilangan acak. Tetapi jika anda menghendaki untuk menginisialiasi kembali bobot dan bias, dapat dilakukan dengan perintah $n e t=$ init $(n e t)$;

berikut ini beberapa perintah yang digunakan untuk menentukan parameter training dalam pelatihan jaringan. di antaranya: untuk menentukan jumlah epoch yang ditampilkan, digunakan perintah :

net.trainParam. show $=500$;

untuk menentukan jumlah learning rate, default $=0.1$, digunakan perintah :

net.trainParam.lr $=0.05$;

untuk menentukan jumlah maximum epoch, digunakan perintah :

net.trainParam.epochs $=20000$;

untuk menentukan jumlah mse terkecil / toleransi, default $=0$, digunakan perintah:

net.trainParam.goal $=1 e-4$;

untuk pelatihan digunakan perintah

$[n e t, t r]=\operatorname{train}(n e t, p, t) ;$
Sedangkan perintah yang digunakan untuk melaksanakan pengujian dengan data yang belum pernah dilatih adalah dengan perintah :

[y,Pf,Af,e,Perf] = sim (net,p,[],[],t);

(Demuth, et.al, 2008.a)

\section{Pelatihan Dengan Arsitektur 24-6-1}

Tujuan dari pelatihan adalah agar Jaringan Syaraf Tiruan melakukan proses pengenalan pola-pola data tinggi signifikan pasang surut laut yang ada yakni data tinggi sifgnifikan pasang surut laut tersebut pada jaringan syaraf dimasukkan pada input layer, kemudian data pada input layer tersebut dipropagasi maju ke hidden layer. Adapun fungsi hidden layer di sini adalah meneruskan sinyal dari input layer sehingga menghasilkan output pada Jaringan Syaraf Tiruan.

Pada Gambar 7 diperlihatkan hasil pelatihan dengan arsitektur 24-6-1, traingscg dengan perintah pengerjaannya pada Matlab sebagai berikut:

> net.trainParam.epochs $=20000$;

> net.trainParam.1r $=0.5$;

> net.trainParam. show $=500$;

> net.trainParam.goal $=1 \mathrm{e}-4$;

$>$ net.trainParam. $\mathrm{mc}=0.8$;

> net=train(net1,pn,tn)

an $=\operatorname{sim}$ (net,pn)TRAINGDX,

Epoch

1000/1000, MSE 0.08331/1e-004, Gradient 0.000789 TRAINGDX, Maximum epoch reached, performance goal was not met. 


\section{Gambar 7. Hasil Pelatihan Dengan Arsitektur 24-6-1}

Gambar 7 memperlihatkan pada saat proses pelatihan pola arsitektur 24-6-1 dengan fungsi pelatihan traingdx dan telah mencapai nilai Mean Square Error (MSE) dengan nilai best training performance is 0.8331 at epoch 1000.

Menampilkan Bobot Awal Yang Diperoleh >>bobotAwal=net.iw $\{1,1\}$

bobotAwal=

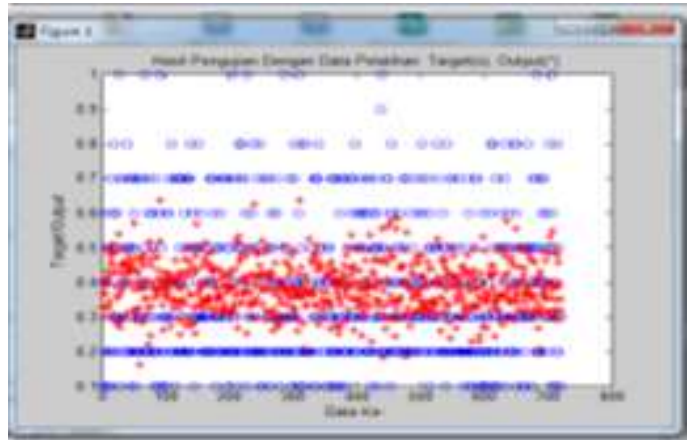

Gambar 8. Hasil Pengujian Dengan Data Pelatihan 24-6-1

Gambar 8 memperlihatkan korelasinya diperoleh 0,08331menunjukan prediksi pasang surut berdasarkan data selama 3 bulan kurang baik.

\section{Pelatihan Dengan Arsitektur 24-12-1}

Pada Gambar 7 diperlihatkan hasil pelatihan dengan arsitektur 24-12-1 traingscg dengan perintah pengerjaannya pada Matlab sebagai berikut:

> net.trainParam.epochs $=20000$;

$\gg$ net.trainParam. $\mathrm{lr}=0.5$;

> net.trainParam. show $=500$;
>> net.trainParam.goal=1e-4;

$>$ net.trainParam $\cdot \mathrm{mc}=0.8$;

$>$ net=train(net1,pn,tn)

an $=\operatorname{sim}($ net,pn)TRAINGDX, Epoch 1000/1000, MSE 0.73682/1e-004, Gradient TRAINGDX, Maximum epoch reached, performance goal was not met.

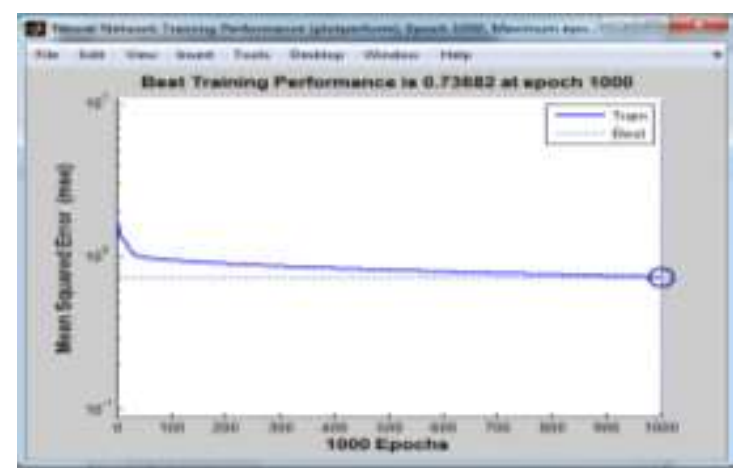

Gambar 9. Hasil Pelatihan Dengan Arsitektur 24-12-1

Gambar 9 memperlihatkan pada saat proses pelatihan pola arsitektur 24-12-1 dengan fungsi pelatihan traingdx dan telah mencapai nilai Mean Square Error (MSE) dengan nilai best training performance is 0.73682 at epoch 1000 .

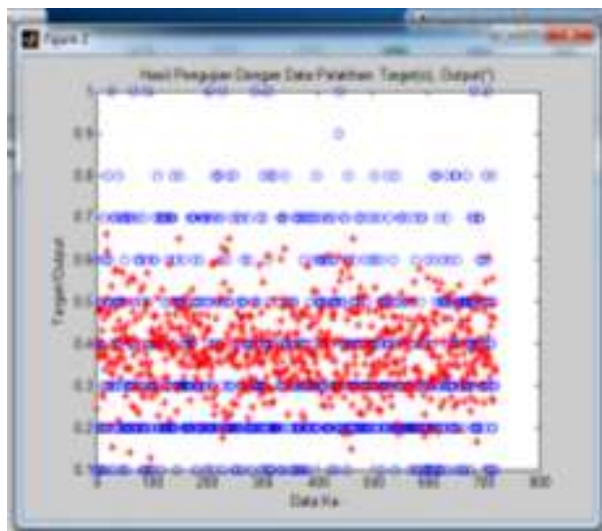

Gambar 10. Hasil Pengujian Dengan Data Pelatihan 24-12-1

Gambar $\quad 10 \quad$ memperlihatkan korelasinya diperoleh 0,73682 menunjukan prediksi pasang surut berdasarkan data selama 3 bulan kurang baik. 


\section{Pelatihan Dengan Arsitektur 24-24-1}

Pada Gambar 11 diperlihatkan hasil pelatihan dengan arsitektur 24-24-1 traingscg dengan perintah pengerjaannya pada Matlab sebagai berikut:

> net.trainParam .epochs $=20000$;

> net.trainParam. $.1 \mathrm{r}=0.5$;

$>$ net.trainParam .show $=500$;

>> net.trainParam.goal=1e-4;

$>$ net.trainParam $. \mathrm{mc}=0.8$;

>> net=train(net1,pn,tn)

an=sim(net,pn)TRAINGDX,

Epoch

1000/1000, MSE 0.73682/1e-004, Gradient

TRAINGDX, Maximum epoch reached, performance goal was not met.

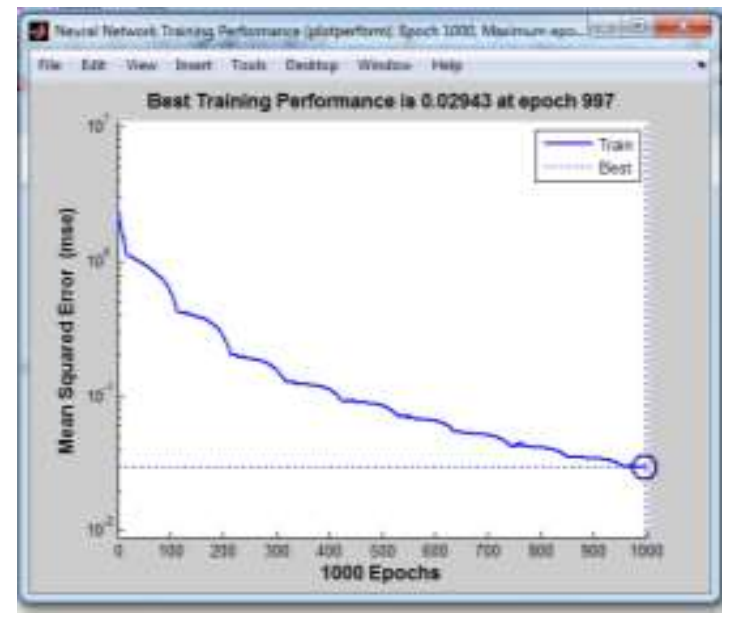

Gambar 11. Pelatihan Dengan Arsitektur 24-24-1

Gambar 11 memperlihatkan pada saat proses pelatihan iterasi berhenti pada iterasi ke 997 dan telah mencapai nilai Mean Square Error (MSE) dengan nilai best training performance is 0.02943 at epoch 1000.

$\operatorname{plot}\left([1: \operatorname{size}(\mathrm{P}, 2)]\right.$ ', $\mathrm{T}, \mathrm{bo}^{\prime},[1: \operatorname{size}(\mathrm{p}, 2)]$ ',a','r*'); title('Hasil Pengujian Dengan Data Pelatihan: Target(o), Output(*)');
xlabel('Data Ke-');ylabel('Target/Output');

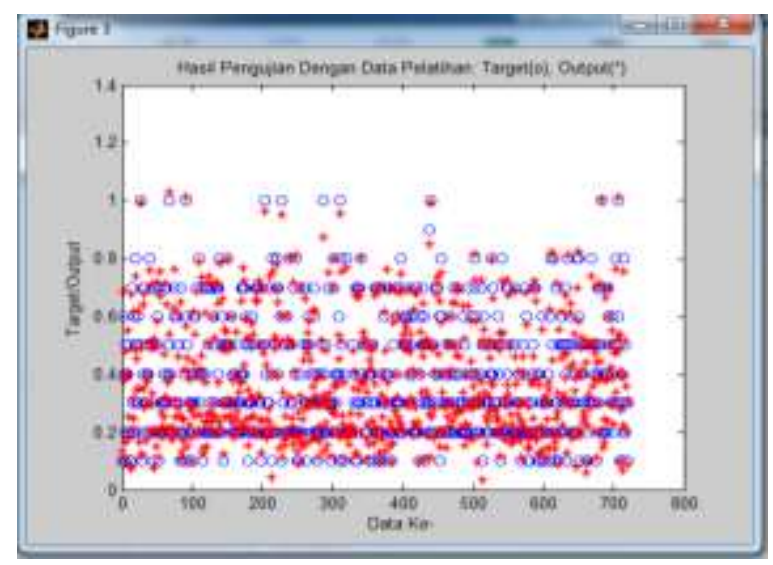

Gambar 12. Hasil Pengujian Dengan Data Pelatihan 24-24-1

Gambar 12 memperlihatkan pada saat proses Neural Network Train Tool (nntraintool) 24-24-1 dengan iterasi ke 997 epoch pada time 0:02:41 diperoleh performance 1.00.e-05 dengan hasil belum mencapai goal.

\section{Pelatihan Dengan Arsitektur 24-48-1}

Pada Gambar 3.8 diperlihatkan hasil pelatihan dengan arsitektur 24-48-1 traingscg dengan perintah pengerjaannya pada Matlab sebagai berikut:

> net.trainParam.epochs $=20000$;

> net.trainParam.lr $=0.5$;

> net.trainParam. show $=500$;

> net.trainParam.goal=1e-4;

$>$ net.trainParam $\cdot \mathrm{mc}=0.8$;

$>$ net=train(net1,pn,tn)

an=sim(net,pn)TRAINGDX,

Epoch

1000/1000, MSE 0.73682/1e-004, Gradient

TRAINGDX, Maximum epoch reached, performance goal was not met 


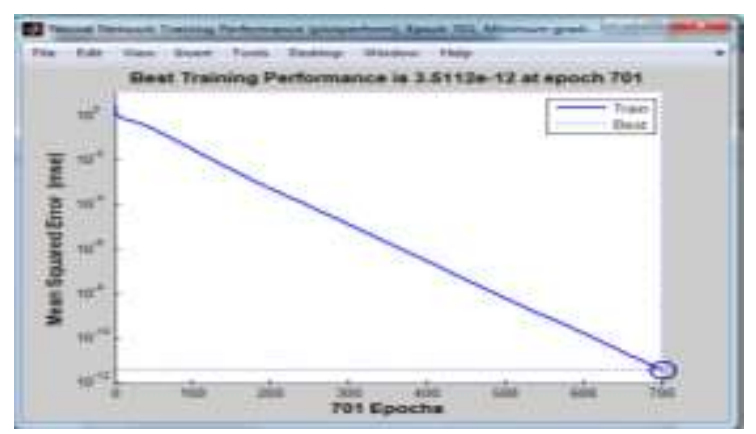

Gambar 13. Pelatihan Dengan Arsitektur 24-48-1

Gambar 13 memperlihatkan pada saat proses pelatihan iterasi berhenti pada iterasi ke 701 dan telah mencapai nilai Mean Square Error (MSE) dengan nilai best training performance is 0.012203 at epoch 701 . $\operatorname{plot}\left([1: \operatorname{size}(\mathrm{P}, 2)]^{\prime}, \mathrm{T}, \mathrm{bo}^{\prime},[1: \operatorname{size}(\mathrm{p}, 2)]^{\prime}, \mathrm{a}^{\prime}, \mathrm{r}^{*}{ }^{*}\right)$; title('Hasil Pengujian Dengan Data Pelatihan: Target(o), Output(*)');

xlabel('Data Ke-');ylabel('Target/Output');

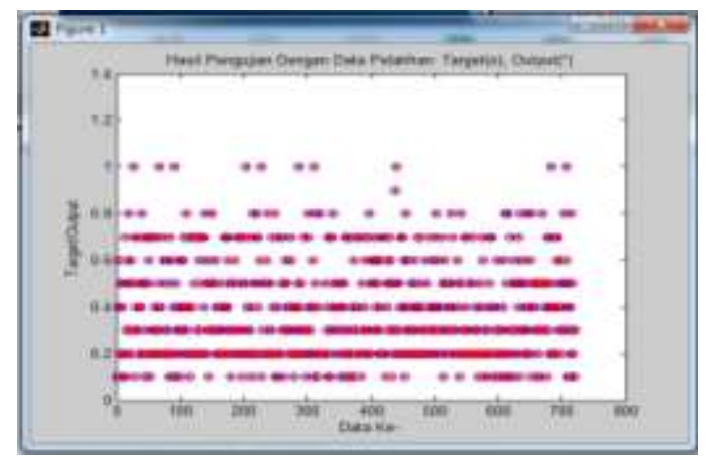

Gambar 13. Hasil Pengujian Dengan Data Pelatihan 24-48-1

Gambar 13 memperlihatkan pada saat proses Neural Network Train Tool (nntraintool) 24-48-1 dengan iterasi ke 1000 epoch pada time 0:03:07 diperoleh performance 0.000100 dengan tingkat prediksi sangat bagus.

\section{Pelatihan Dengan Arsitektur 24-96-1}

Pada Gambar 14 diperlihatkan hasil pelatihan dengan arsitektur 24-96-1 trainslm dengan perintah pengerjaannya pada Matlab sebagai berikut:

>> net.trainParam.epochs $=20000$;

> net.trainParam.lr $=0.5$;

$>$ net.trainParam . show $=500$;

> net.trainParam.goal $=1 \mathrm{e}-4$;

$>$ net.trainParam $\cdot \mathrm{mc}=0.8$;

> net=train(net1,pn,tn)

an $=\operatorname{sim}($ net,pn)TRAINGDX,

Epoch 1000/1000, MSE 0.73682/1e-004, Gradient TRAINGDX, Maximum epoch reached, performance goal was not met.

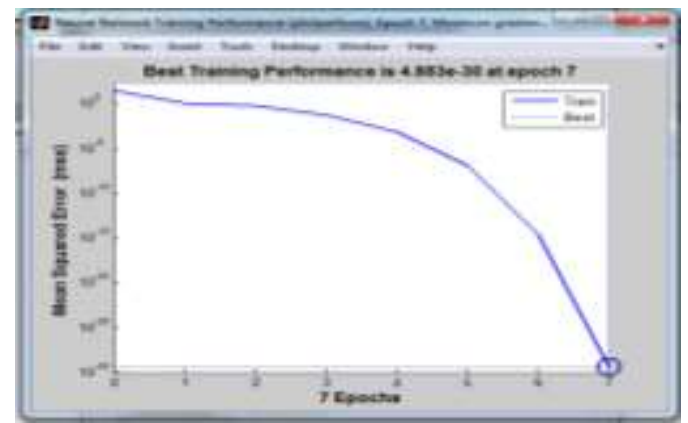

Gambar 14. Hasil Pelatihan Dengan Arsitektur 24-96-1

Gambar 14 memperlihatkan pada saat proses pelatihan iterasi berhenti pada iterasi ke 7 dan telah mencapai nilai Mean Square Error (MSE) dengan nilai best training performance is $04.883 \mathrm{e}-30$ at epoch 7.

plot([1:size(P,2)]',T,'bo',[1:size(p,2)]',a','r*'); title('Hasil Pengujian Dengan Data Pelatihan: Target(o), Output $\left.(*)^{\prime}\right)$; xlabel('Data Ke-');ylabel('Target/Output'); 


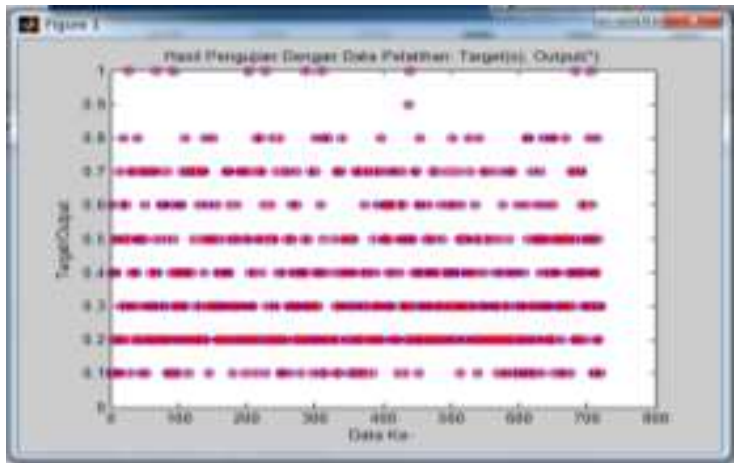

Gambar 15. Hasil Pengujian DenganData 24-96-1

Gambar 15 memperlihatkan pada saat proses Neural Network Train Tool (nntraintool) 24-96-1 dengan iterasi ke 7 epoch pada time 0:00:23 diperoleh performance 1.000100 dengan nilai prediksi sangat akurat atau mencapai goal.

\subsection{Rekapitulasi Hasil Pelatihan}

Rekapitulasi hasil pelatihan dengan 15 test bed yang berbeda-beda, didapat rekapitulasi masing-masing pelatihan yang disajikan pada Tabel berikut ini :

Tabel 1.

Hasil Pelatihan Dengan Test Bed Yang Berbeda-beda

\begin{tabular}{|c|c|c|c|c|c|}
\hline No & $\begin{array}{l}\text { Arsit } \\
\text { ektur }\end{array}$ & $\begin{array}{l}\text { Leami } \\
\text { ng } \\
\text { functi } \\
\text { on }\end{array}$ & $\begin{array}{c}\text { Epo } \\
\text { ch } \\
\max \end{array}$ & MSE & $\begin{array}{c}\text { Menca } \\
\text { pai } \\
\text { goal }\end{array}$ \\
\hline 1 & $\begin{array}{l}24-6- \\
1\end{array}$ & $\begin{array}{l}\text { Traing } \\
\mathrm{dx}\end{array}$ & $\begin{array}{l}100 \\
0\end{array}$ & 0.8331 & Tidak \\
\hline 2 & $\begin{array}{l}24- \\
12-1\end{array}$ & $\begin{array}{l}\text { Traing } \\
\mathrm{dx}\end{array}$ & $\begin{array}{l}100 \\
0\end{array}$ & $\begin{array}{l}0.7368 \\
2\end{array}$ & Tidak \\
\hline 3 & $\begin{array}{l}24- \\
24-1\end{array}$ & $\begin{array}{l}\text { Traing } \\
\mathrm{dx}\end{array}$ & 997 & $\begin{array}{l}0.0294 \\
3\end{array}$ & Tidak \\
\hline 4 & $\begin{array}{l}24- \\
48-1\end{array}$ & $\begin{array}{l}\text { Traing } \\
\mathrm{dx}\end{array}$ & $\begin{array}{l}100 \\
0\end{array}$ & $\begin{array}{l}0.0149 \\
91\end{array}$ & Tidak \\
\hline 5 & $\begin{array}{l}24- \\
96-1\end{array}$ & $\begin{array}{l}\text { Trainl } \\
\mathrm{m}\end{array}$ & 7 & $\begin{array}{l}4.883 \mathrm{e} \\
-30\end{array}$ & $\mathrm{Ya}$ \\
\hline
\end{tabular}

Tabel 1 di atas memberikan gambaran bahwa dari 5 kali pelatihan dengan arsitektur yang berbeda-beda, ternyata hanya 1 arsitektur yang dapat mencapai gol. Hal ini menunjukkan bahwa jumlah neuron sebagai unit pengolah sangat menentukan berhasil atau tidaknya pengenalan pola oleh Jaringan Syaraf Tiruan. Demikian juga dengan learning functionnya. Hasil pengujian menunjukkan bahwa hanya pada learning function trainlm yang berhasil mencapai target, sementara pada pelatihan dengan learning function traingdx maupun trainscg, tak ada satupun yang berhasil mencapai target.

Metode standar Backpropagation sering kali terlalu lambat untuk keperluan praktis. Beberapa modifikasi dilakukan terhadap standar Backpropagation dengan cara mengganti fungsi pelatihannya.

Secara umum, modifikasi dapat dikelompokkan kedalam 2 Kategori. Kategori pertama adalah metode menggunakan metode heuristik, yang dikembangkan dengan metode tercepat yang di pakai dalam standar Backpropagation. Kategori kedua adalah dengan menggunakan metode optimisasi numerik selain penurunan tercepat. Fungsi pelatihan terakhir, yaitu fungsi trainlm merupakan salah satu metode penurunan tercepat, disamping metode penurunan pelatihan lainnya, seperti traincbg, trainnrp, traincbf, trainoss dan lain-lain, sehingga dapat melatih Jaringan Syaraf Tiruan yang dapat mencapai goal lebih cepat dibanding fungsi defaulnya, yaitu traingdx/traingda. 


\section{KESIMPULAN}

Dari hasil penelurusan dengan berbagai tahapan, didapat kesimpulan bahwa :

1. Teknik Jaringan Syaraf Tiruan ternyata mampu memprediksi tinggi pasang surut laut di Stasiun Klimatologi Pulau Baai Bengkulu sesuai dengan goal yang diharapkan.

2. Arsitektur Jaringan Syarat Tiruan sangat mempengaruhi keakurasian hasil pendugaan yang dihasilkan.

3. Dari berbagai pengujian, jaringan dengan arsitektur 24-96-1 trainlm memberikan nilai akurasi yang sempurna dengan nilai $100 \%$.

4.

$$
\text { akurasi }=\left[1-\left[\frac{\frac{1}{2} \sum_{i=1}^{N}\left(t_{i}-o_{i}\right)^{2}}{N}\right]\right] * 100
$$

$$
\text { akurasi }=\left[1-\left[\frac{\frac{1}{2}(0)}{720}\right]\right] * 100
$$

\section{DAFTAR RUJUKAN}

\section{http://bengkuluprov.go.id/profil/geografi/}

Alfi Faridatus Sa'adah, Dwi Ispriyanti, SupartiPrediksi Tinggi Pasang Air LautDi Kota Semarang Dengan Menggunakan Metode Seasonal Autoregressive Integrated Moving Average (Sarima) Dan DeteksiOutlier. Jurnal Gaussian, Volume3, Nomor 3, Tahun 2014, Halaman 273 - 282
Youllia Indrawaty, Asep Nana Hermana, Akbar RamadhanImplementasi Model Backpropagation Dalam Mengenali Pola Gambar Untuk Mendiagnose Penyakit Kulit. Itenas Library, No.1 , Vol. 3, Januari - April 2012Maneesh ShreevastavaMedical Diagnosis using Back propagation Algorithm. International Journal of Emerging Technology and Advanced Engineering, ISSN 2250-2459, Volume 1, Issue 1, November 2011

Norhamreeza Abdul Hamid, Nazri Mohd Nawi, Rozaida Ghazali, Mohd Najib Mohd Salleh. Accelerating Learning Performance of Back Propagation Algorithm by Using Adaptive Gain Together with Adaptive Momentum and Adaptive Learning Rate on Classification Problems. International Journal of Software Engineering and Its Applications Vol. 5 No. 4, October, 2011

Sassi,R.J, Da Silva, Emilio Del Moral Hernandez, Neural Networks and Rough Sets: A comparative study on data classification. 